\title{
Can China keep its end up?
}

\section{Hong Kong}

WESTERN companies are concerned about China's ability to enforce a new agreement with the United States on intellectual property rights that takes effect this month.

The agreement, part of a memorandum of understanding (MOU) signed by the two countries on 17 January, strengthens Chinese laws in exchange for ending a special investigation by US officials into its trade practices. Among other things, China has agreed to join the Berne Copyright Convention and the Geneva Phonograms Convention within 18 months, as well as to move quickly to pass laws that would expand protection of copyrights, patents and trade secrets. The laws would also apply to such intellectual property owned by foreigners.

But Western lawyers are worried about the vague language in the MOU. The English version of the document is filled with such phrases as "China will use its best efforts" to protect foreign works and will act "within a reasonable period of time". Jeffrey Siebach, regional representative for the Business Software Alliance based in Washington, DC, says that "the variables really can be quite daunting. It's economically unacceptable uncertainty".

Observers also wonder if Chinese officials, both in the capital and throughout the provinces, are prepared to enforce the new rules. One major question is which ministry will be responsible. Most multinational companies want it to be the $\mathrm{Na}$ tional Copyright Administration, which is thought to be impartial. They fear that if the job goes to the Ministry of Machine Building and Electronics Industry, which in the past has taken a protectionist attitude toward the issue, it could sabotage any chance of legislation.

At the same time, the industry ministry has more technical expertise to administer the new rules and more power over Chinese software companies. That knowledge could be very helpful, says Joseph Simone, a Hong Kong lawyer and specialist in Chinese investment. Simone and other lawyers representing Western software companies discussed the matter last week with ministry officials in Beijing.

Another problem is that infringements of patents and copyrights are covered by China's civil code, and not its criminal code. That situation forces aggrieved companies to take their complaints to local authorities. Although some US software companies have said they want to act quickly to protect their patents, they must first find out where to bring their case. In addition, the costs of litigation could well exceed the losses from piracy. Simone, for one, suggests that Western companies would do better to ask local authorities to

\section{Red tape delays funds for Amazonia}

\section{São Paulo}

THE presidents of six Amazonia countries have once again complained that the industrialized nations must do more to stop emissions of greenhouse gases and must spend more on efforts to achieve sustained development of the region. But what the leaders did not talk about at their meeting last month in Manaus was how a considerable amount of money for research and environmental protection already committed by the industrial world is being held up by their own bureaucratic inefficiencies.

"We want access to clean technologies and other means of protecting the environment," said Brazil's president, Fernando Collor de Mello. He failed to mention, however, that his country paid more than $\$ 1$ million in fines last year because it failed to use $\$ 150$ million lent to it in 1989 by the World Bank to study and protect the Atlantic forest, the Pantanal wetlands and the Amazon rainforest. The government was penalized for failing to pay its share of the multi-million dollar programme. $\mathrm{He}$ also kept silent about a German-funded project to protect the Atlantic forest that is stalled in his country's Congress.
But the environment isn't the only loser. Two research institutes, the National Institute for Amazonian Research (INPA) in Manaus and the Belèn-based Emilio Goeldi Museum, have waited several months for delivery of some $\$ 80$ million promised by the G-7 group of industrial countries that require some matching funds from the Brazilian government. But those funds cannot flow until politicians resolve the country's annual budget battle.

In the meantime, research staffs are being starved for funds. "We do not even have Xerox machines, complains Philip Fearnside, an INPA researcher, "because the institute cannot pay the rent."

INPA's director, Eneas Salati, agrees that the institute may not have money to pay its telephone bills and that office machines must be turned off periodically to conserve a dwindling budget. "It's the beginning of the year, and the budget has not yet been allocated," he says. The interest on the $\$ 50$ million over five years that the G-7 nations have pledged would be a significant boost to his institute's current annual budget of about $\$ 10$ million. But Salati has no idea when the money is likely to turn up.

Ricardo Bonalume negotiate settlements than to take their complaints to the courts.

Chinese and Western sources disagree about the amount of money at stake. US industry claims that it loses more than $\$ 300$ million a year as a result of Chinese theft of copyrights. Software companies alone estimate their annual losses at $\$ 160$ million, on the basis of the difference between actual and expected sales to a country with half million personal computers.

Zheng Songyu, general manager of the China Patent Agency, a joint venture between Hong Kong and China, thinks that those figures are greatly inflated. He concedes that Chinese companies have copied Western software, but he argues that they have done so mostly for their own use, rather than for commercial gain. $\mathrm{He}$ estimates that $\$ 30$ million would be a more accurate figure on annual losses to Western companies.

In a speech last December, Zheng predicted that it would take China up to five years to achieve full protection for intellectual property rights. Thanks to the MOU, he says, that process should move ahead much more quickly. Peter Gwynne

INTELLECTUAL PROPERTY

\section{US and India in row}

\section{Washington}

A NINE-MONTH investigation by the United States into Indian patent and trademark policies has found gaping holes in its laws and policies and invoked threats of possible trade sanctions. US officials found that India provides no patent protection for pharmaceuticals products and only a very short protection period for other patents, and that foreign patent holders are required to license their products to Indian companies.

US pharmaceutical manufacturers claim that the Indian rules and "rampant piracy" cost them $\$ 200$ million in lost sales in India. Indian companies also sell another $\$ \mathbf{2 0 0}$ million of pirated drugs to other developing countries, according to the Pharmaceutical Manufacturing Association.

Prompted by the US investigation and its own internal inquiry, the Indian parliament is considering a measure to improve enforcement of copyrights and has started compiling data on copyright abuse. The government has begun to train policy officers and prosecutors in copyright law. India also has promised that foreign holders of trademarks will be given the same status as Indian nationals.

US officials are resisting pressure from US pharmaceutical makers to seek "retaliation" for India's current policies. US trade representative Carla Hills, who is negotiating with the Indian government, said she was "leaving the door open" in the hope that India will make positive changes.

Christopher Anderson 